\title{
KEANEKARAGAMAN HYMENOPTERA PARASITIKA PADA TIPE EKOSISTEM BERBEDA DI BANGKA TENGAH, KEPULAUAN BANGKA BELITUNG
}

\author{
Herry Marta Saputra ${ }^{1}$, Nina Maryana ${ }^{2}$, \& Pudjianto ${ }^{2}$ \\ ${ }^{1}$ Program Studi Entomologi, Sekolah Pascasarjana, Fakultas Pertanian, Institut Pertanian Bogor \\ Jl. Kamper Kampus IPB Dramaga, Bogor, Indonesia 16680 \\ ${ }^{2}$ Departemen Proteksi Tanaman, Fakultas Pertanian, Institut Pertanian Bogor \\ Jl. Kamper Kampus IPB Dramaga, Bogor, Indonesia 16680 \\ Email: hartsaputra3103@gmail.com
}

\begin{abstract}
Diversity of parasitic Hymenoptera in different ecosystem types in Central Bangka, Bangka-Belitung Islands. Hymenoptera richness is dominated by parasitic species. More than $80 \%$ of Hymenoptera play a role as parasitoid on arthropods that are mostly insects. Diversity of parasitic Hymenoptera is widely studied in various types of terrestrial ecosystems including agroecosystem and non-agro-ecosystem. This study aimed to invent and compare the diversity of parasitic Hymenoptera in three different ecosystems in Central Bangka Regency, Bangka Island, i.e., forest, oil palm plantation, and ex-tin mining. The study was conducted in Juli 2014 until October 2015. Parasitic Hymenoptera was collected with insect sweep net and yellow pan trap on one transect line with $1000 \mathrm{~m}$ length. Parasitic Hymenoptera were found on forest as much as 732 morphospecies, 326 morphospecies on oil palm plantations, and 293 morphospecies on ex-tin mining. Diversity and abundance of parasitic Hymenoptera on forest was higher than oil palm plantation and ex-tin mining area. Braconidae family was found dominant on forest, however on oil palm plantation and ex-tin mining area the dominant family was Scelionidae.
\end{abstract}

Key words: Parasitic Hymenoptera, diversity, forest, oil palm plantation, ex-tin mining

\begin{abstract}
ABSTRAK
Keanekaragaman Hymenoptera parasitika pada tipe ekosistem berbeda di Bangka Tengah, Kepulauan Bangka Belitung. Kekayaan Hymenoptera didominasi oleh spesies parasitoid. Lebih dari 80\% Hymenoptera berperan sebagai parasitoid pada artropoda yang umumnya adalah serangga. Keanekaragaman Hymenoptera parasitika dipelajari secara luas di berbagai tipe ekosistem terestrial yakni agroekosistem dan non-agroekosistem. Penelitian ini bertujuan untuk mengiventarisasi dan membandingkan keanekaragaman Hymenoptera parasitika pada tiga tipe ekosistem berbeda, yaitu hutan, perkebunan kelapa sawit, dan area pasca tambang timah. Lokasi penelitian terletak di Kabupaten Bangka Tengah, Pulau Bangka. Penelitian dilakukan pada Juli 2014 hingga Oktober 2015. Hymenoptera parasitika dikoleksi dengan jaring ayun serangga dan perangkap nampan kuning pada satu garis transek yang telah ditentukan sepanjang $1000 \mathrm{~m}$. Hymenoptera parasitika yang ditemukan di hutan sebanyak 732 morfospesies, 326 morfospesies pada perkebunan kelapa sawit, dan 293 morfospesies pada area pasca tambang timah. Keanekaragaman dan kelimpahan Hymenoptera Parasitika pada hutan lebih tinggi dibandingkan dengan perkebunan kelapa sawit dan area pasca tambang timah. Famili Braconidae ditemukan lebih dominan pada hutan, sedangkan pada perkebunan kelapa sawit dan area pasca tambang timah famili yang dominan adalah Scelionidae.
\end{abstract}

Kata kunci: Hymenoptera parasitika, keanekaragaman, hutan, perkebunan kelapa sawit, area pasca tambang timah

\section{PENDAHULUAN}

Hymenoptera merupakan ordo serangga terbesar ke-tiga setelah Lepidoptera dan Coleoptera (Grimaldi \& Engel, 2005). Ordo ini terdiri atas serangga fitofag, serangga sosial, lebah, tabuhan soliter dan parasitoid (Wharton, 1997). Walaupun lebah, tabuhan dan semut umumnya lebih dikenal dalam Ordo Hymenoptera akan tetapi Hymenoptera parasitika mempunyai keanekaragaman yang tinggi di dalam ordo ini.
Berdasarkan peranan di alam, sekitar 80\% dari kelompok Hymenoptera didominasi oleh spesies parasitoid. Spesies lainnya adalah fitofag, polinator dan predator (Quicke, 1997).

Keanekaragaman spesies khususnya Hymenoptera parasitika merupakan salah satu topik utama dalam penelitian ekologi untuk mempelajari susunan dan komposisi spesies serta kelimpahannya dalam suatu ekosistem. Sharkey (2007) menyatakan bahwa parasitoid sensitif terhadap perubahan dan 
kerusakan habitat. Ekosistem yang berbeda dapat mempengaruhi keanekaragaman spesies Hymenoptera parasitika yang hidup di dalamnya terutama kekayaan spesies.

Tumbuhan dan serangga saling berinteraksi di ekosistem. Keanekaragaman Hymenoptera parasitika mengikuti keanekaragaman serangga fitofag yang menjadi inang parasitoid dan keanekaragaman serangga fitofag bergantung pada tumbuhan yang tersedia di ekosistem (Sahari, 2012). Berdasarkan karakteristik vegetasi, kawasan hutan dicirikan dengan komunitas tumbuhan yang didominasi oleh pepohonan dan tumbuhan berkayu lainnya dengan berbagai stratifikasi tajuk (Spurr \& Barnes, 1980), sedangkan perkebunan kelapa sawit dicirikan dengan dominannya tumbuhan vegetasi bawah seperti gulma teki-tekian, gulma rumputrumputan, gulma daun lebar, dan gulma pakisan (Adriadi et al., 2012). Pada lahan pasca tambang timah di Bangka, vegetasi tumbuhan terdiri atas rerumputan, herba, semak, dan pohon tertentu yang adaptif terhadap kondisi lahan pasca tambang (Nurtjahya, 2008). Lestari et al. (2008) menyatakan bahwa tumbuhan dominan pada lahan pasca tambang timah adalah kedebik (Melastoma malabathricum L.) dan mentenuk (Commersonia sp.). Berdasarkan hal tersebut, keanekaragaman Hymenoptera Parasitika di tipe ekosistem yang berbeda tersebut menarik untuk diteliti. Penelitian ini bertujuan untuk menginventarisasi dan membandingkan keanekaragaman Hymenoptera Parasitika pada hutan, perkebunan kelapa sawit, dan area pasca tambang timah di Kabupaten Bangka Tengah, Kepulauan Bangka Belitung.

\section{METODE PENELITIAN}

Tempat dan waktu. Penelitian dilakukan di Kabupaten Bangka Tengah, Bangka, Provinsi Kepulauan Bangka Belitung. Identifikasi Hymenoptera Parasitika dilakukan di Laboratorium Biosistematika Serangga, Departemen Proteksi Tanaman, Fakultas Pertanian, Institut Pertanian Bogor. Identifikasi tumbuhan dilakukan di Laboratorium Bidang Botani Puslit Biologi, Lembaga Ilmu Pengetahuan Indonesia, Cibinong. Penelitian dilaksanakan mulai bulan Juli 2014 sampai Oktober 2015.

Penentuan Lokasi. Lokasi penelitian ditentukan dengan memilih tiga lokasi untuk hutan, tiga lokasi perkebunan kelapa sawit, dan tiga lokasi area pasca tambang timah. Penelitian di hutan dilakukan pada kawasan lindung yang terletak di Desa Namang, Terentang III dan Trubus. Penelitian di perkebunan kelapa sawit dilakukan pada lahan pertanaman kelapa sawit dengan umur 2 hingga 3 tahun setelah tanam yang terletak di Desa Jongkong V, Arung Dalam dan Padang Mulya. Penelitian di area pasca tambang timah dilakukan pada lahan vegetasi suksesi alami dengan umur \pm 3 tahun sejak tidak dieksploitasi lagi yang terletak di Desa Kulur Ilir, Jongkong V dan Jongkong XII. Lokasi penelitian ditampilkan pada Gambar 1.

Koleksi Hymenoptera Parasitika. Di setiap lokasi penelitian ditentukan satu garis transek sepanjang 1000 $\mathrm{m}$ dan jika lokasi penelitian tidak mencapai jarak tersebut, maka diadakan pembelokan kembali ke arah semula

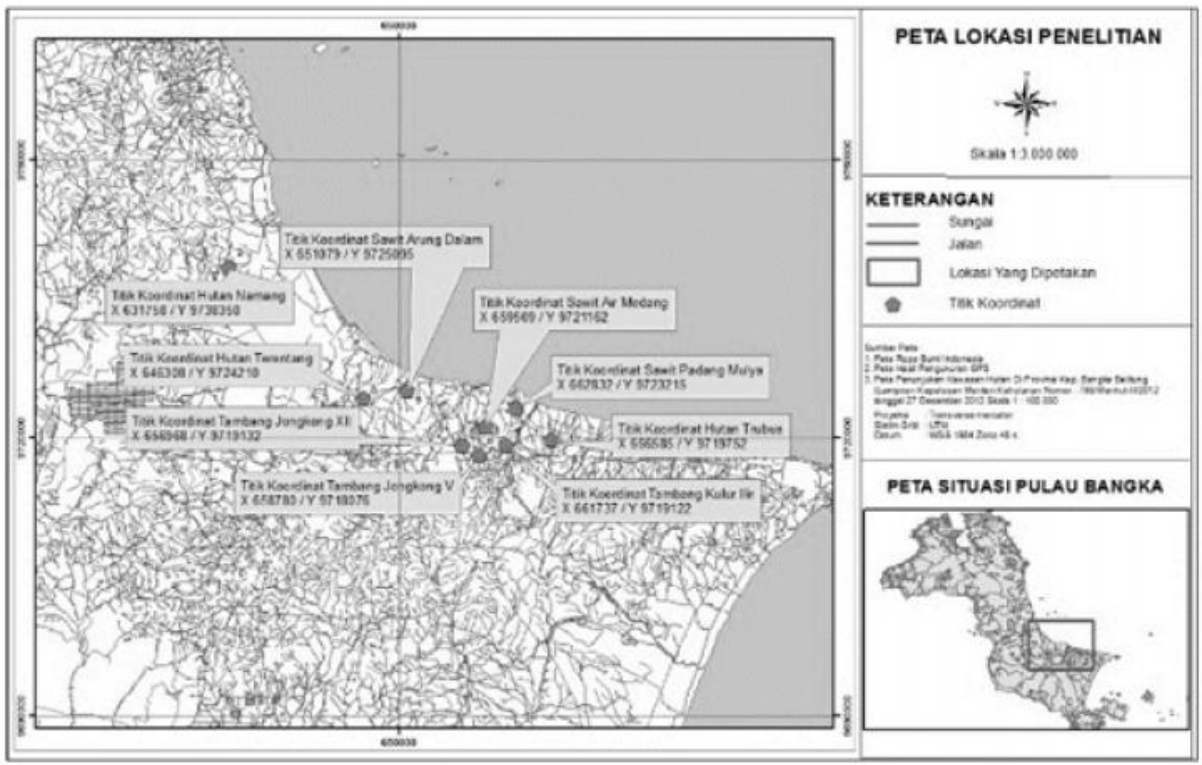

Gambar 1. Peta lokasi penelitian di Kabupaten Bangka Tengah, Provinsi Kepulauan Bangka Belitung 
(Hamid et al., 2003). Koleksi Hymenoptera Parasitika di masing-masing lokasi penelitian dilakukan dengan jaring ayun serangga sebanyak dua kali dan perangkap nampan kuning sebanyak satu kali pengambilan.

Penjaringan Hymenoptera parasitika dilakukan selama dua hari berturut-turut pada pukul 09.00-12.00 WIB. Penjaringan serangga dilakukan dengan mengayunkan jaring ke kiri dan ke kanan sambil berjalan di sepanjang garis transek $1000 \mathrm{~m}$. Jika panjang lokasi penelitian tidak mencapai jarak tersebut, maka garis dibelokkan ke arah semula dengan jarak $100 \mathrm{~m}$ dari garis yang telah dilewati. Total ayunan di sepanjang garis transek 1000 m adalah 1500 kali ayunan ganda. Hasil penjaringan serangga dimasukkan ke dalam separator setiap 10 kali ayunan ganda.

Perangkap nampan kuning dipasang pada pukul 09.00 WIB. Perangkap nampan kuning digunakan untuk memerangkap serangga yang tertarik pada warna kuning. Jumlah nampan kuning yang dipasang di sepanjang garis transek $1000 \mathrm{~m}$ adalah 50 buah dengan jarak antara nampan kuning $20 \mathrm{~m}$. Nampan kuning yang digunakan terbuat dari wadah plastik berbentuk piring dengan diameter bawah (alas) $20 \mathrm{~cm}$, diameter atas $26 \mathrm{~cm}$ dan tinggi $3 \mathrm{~cm}$. Nampan kuning diletakkan di atas permukaan tanah yang terbuka agar mudah dilihat oleh serangga. Setelah nampan kuning diletakkan di atas permukaan tanah, larutan deterjen dimasukkan sebanyak setengah dari tinggi nampan kuning. Larutan deterjen digunakan untuk mengurangi tegangan permukaan air sehingga serangga akan tenggelam dan akhirnya mati. Serangga yang terperangkap di dalam nampan kuning diambil setelah 1 x 24 jam.

Pengamatan Vegetasi. Sepanjang garis transek ditentukan lima plot vegetasi yang berukuran $8 \times 8 \mathrm{~m}$ dengan jarak antar plot $200 \mathrm{~m}$. Tumbuhan yang diidentifikasi sampai tahap spesies adalah rerumputan, semak, liana, dan semai (diameter batang $<2 \mathrm{~cm}$ dengan tinggi $\leq 1.5 \mathrm{~m})(\mathrm{BSN}, 2011)$. Tumbuhan yang dikoleksi dibuat herbarium kering untuk memudahkan proses identifikasi.

Identifikasi Serangga. Hymenoptera parasitika hasil tangkapan di lokasi penelitian diidentifikasi di laboratorium. Hymenoptera parasitika diidentifikasi dengan beberapa kunci identifikasi (Grissell \& Schauff, 1990; Goulet \& Huber, 1993; Gibson et al., 1997). Familifamili Hymenoptera parasitika diidentifikasi sampai tingkat morfospesies.

Analisis Data. Hasil identifikasi serangga ditabulasikan dalam tabel pivot pada perangkat lunak Microsoft Excel untuk menjadi database. Data kemudian diproses dengan program $R$ statistic 3.0.2 paket vegan untuk menampilkan nilai indeks keanekaragaman ShannonWiener, indeks kemerataan spesies dan kekayaan spesies. Perbedaan nilai indeks keanekaragaman ShannonWiener, indeks kemerataan spesies, kekayaan spesies dan kelimpahan spesies antar lokasi penelitian dianalisis dengan menggunakan analisis ragam (Oneway Anova). Jika hasil analisis ragam menunjukkan pengaruh nyata maka dilanjutkan dengan uji lanjut DMRT (Duncan's multiple range test) pada taraf kepercayaan $95 \%$ dengan perangkat lunak SAS versi 9.1.3 (Yaherwandi et al., 2007).

\section{HASIL DAN PEMBAHASAN}

Keanekaragaman Hymenoptera Parasitika. Keanekaragaman Hymenoptera parasitika yang didapatkan dengan jaring ayun serangga dan perangkap nampan kuning di semua tipe ekosistem adalah 32 famili dan 1151 morfospesies. Hymenoptera Parasitika yang didapatkan di hutan, perkebunan kelapa sawit dan area pasca tambang timah masing-masing adalah 732, 326 dan 293 morfospesies (Tabel 1). Hasil tersebut menunjukkan bahwa morfospesies Hymenoptera Parasitika di hutan dua kali lebih tinggi dibandingkan dengan dua tipe ekosistem lainnya. Berdasarkan kekayaan morfospesies, famili Braconidae mempunyai kekayaan morfospesies tertinggi dibandingkan dengan famili lainnya. Kekayaan morfospesies Braconidae di hutan mencapai enam hingga tujuh kali lebih tinggi dibandingkan dengan dua ekosistem lainnya. Hal ini sejalan dengan penelitian Maeto et al. (2009) dan RuizGuerra et al. (2015) yang melaporkan bahwa spesies Braconidae lebih tinggi ditemukan pada hutan dibandingkan dengan non-hutan.

Morfospesies Hymenoptera parasitika yang hanya ditemukan pada ekosistem tertentu akan tetapi tidak ditemukan pada ekosistem lainnya dinamakan spesies unik. Morfospesies unik Hymenoptera Parasitika pada hutan, perkebunan kelapa sawit dan area pasca tambang timah berturut-turut adalah 623, 182 dan 170 morfospesies (Gambar 2).

Morfospesies unik Hymenoptera Parasitika yang terdapat pada masing-masing tipe ekosistem menandakan bahwa morfospesies tersebut terbatas hanya pada ekosistem itu. Morfospesies unik Hymenoptera Parasitika pada hutan yang lebih tinggi dibandingkan dengan dua tipe ekosistem lainnya disebabkan oleh jenis tumbuhan dan serangga yang lebih beragam. Rott \& Godfray (2000) menyatakan bahwa komunitas parasitoid terutama dipengaruhi oleh tumbuhan makanan inang. 
Jenis tumbuhan yang lebih beragam akan menyediakan lebih beragam serangga dan parasitoid spesialisnya (Shaw, 2006). Jenis tumbuhan yang terdapat pada hutan, perkebunan kelapa sawit dan area pasca tambang timah berturut-turut adalah 64, 35 dan 30 spesies tumbuhan (Tabel 2).
Morfospesies Hymenoptera Parasitika yang terdapat pada tiga tipe ekosistem sebanyak 24 morfospesies. Morfospesies Hymenoptera tersebut memiliki persebaran yang luas. Diduga morfospesies Hymenoptera tersebut dapat ditemukan pada tiga lokasi yang berbeda dikarenakan ketersediaan serangga inang.

Tabel 1. Keanekaragaman Hymenoptera parasitika pada masing-masing tipe ekosistem

\begin{tabular}{|c|c|c|c|c|}
\hline \multirow[b]{2}{*}{ Superfamili/famili } & \multicolumn{3}{|c|}{ Kekayaan morfospesies } & \multirow[b]{2}{*}{ Total morfospesies } \\
\hline & Hutan & $\begin{array}{c}\text { Perkebunan } \\
\text { kelapa sawit }\end{array}$ & $\begin{array}{l}\text { Pasca tambang } \\
\text { timah }\end{array}$ & \\
\hline \multicolumn{5}{|l|}{ Chrysidoidea } \\
\hline Bethylidae & 9 & 10 & 7 & 20 \\
\hline Chrysididae & 0 & 2 & 1 & 2 \\
\hline Dryinidae & 7 & 2 & 3 & 11 \\
\hline \multicolumn{5}{|l|}{ Vespoidea } \\
\hline Mutillidae & 4 & 1 & 1 & 5 \\
\hline Scoliidae & 1 & 2 & 3 & 4 \\
\hline Tiphiidae & 1 & 0 & 1 & 1 \\
\hline \multicolumn{5}{|l|}{ Ichneumonoidea } \\
\hline Braconidae & 256 & 41 & 35 & 302 \\
\hline Ichneumonidae & 49 & 18 & 19 & 80 \\
\hline \multicolumn{5}{|l|}{ Evanioidea } \\
\hline Evaniidae & 5 & 6 & 7 & 13 \\
\hline Gasteruptiidae & 1 & 0 & 1 & 2 \\
\hline \multicolumn{5}{|l|}{ Cynipoidea } \\
\hline Eucoilidae & 12 & 11 & 5 & 19 \\
\hline \multicolumn{5}{|l|}{ Proctotrupoidea } \\
\hline Diapriidae & 38 & 15 & 12 & 57 \\
\hline \multicolumn{5}{|l|}{ Platygastroidea } \\
\hline Platygastridae & 21 & 5 & 6 & 28 \\
\hline Scelionidae & 34 & 52 & 51 & 113 \\
\hline \multicolumn{5}{|l|}{ Ceraphronoidea } \\
\hline Ceraphronidae & 21 & 18 & 6 & 35 \\
\hline Megaspilidae & 0 & 0 & 1 & 1 \\
\hline \multicolumn{5}{|l|}{ Chalcidoidea } \\
\hline Aphelinidae & 24 & 3 & 5 & 30 \\
\hline Chalcididae & 7 & 16 & 6 & 16 \\
\hline Elasmidae & 8 & 9 & 8 & 15 \\
\hline Encyrtidae & 62 & 24 & 24 & 93 \\
\hline Eucharitidae & 5 & 1 & 4 & 10 \\
\hline Eulophidae & 78 & 43 & 39 & 135 \\
\hline Eupelmidae & 15 & 7 & 9 & 27 \\
\hline Eurytomidae & 7 & 3 & 7 & 14 \\
\hline Mymaridae & 35 & 8 & 11 & 46 \\
\hline Ormyridae & 1 & 0 & 0 & 1 \\
\hline Perilampidae & 0 & 4 & 1 & 5 \\
\hline Pteromalidae & 15 & 19 & 8 & 34 \\
\hline Signiphoridae & 0 & 0 & 1 & 1 \\
\hline Torymidae & 5 & 1 & 2 & 6 \\
\hline Trichogrammatidae & 11 & 5 & 8 & 24 \\
\hline \multicolumn{5}{|l|}{ Mymarommatoidea } \\
\hline Mymarommatidae & 0 & 0 & 1 & 1 \\
\hline Total & 732 & 326 & 293 & 1151 \\
\hline
\end{tabular}


Ketertarikan Hymenoptera Parasitika untuk mendiami suatu ekosistem dikarenakan kesesuaian mikrohabitat, ketersediaan makanan (polen, nektar, dan embun madu) dan ketersediaan inang parasitoid yang berasosiasi dengan jenis tanaman tertentu di suatu ekosistem (Sperber et al., 2004).

Dominansi Hymenoptera Parasitika. Hymenoptera Parasitika yang dikoleksi pada semua tipe ekosistem sebanyak 6937 individu (Tabel 3). Berdasarkan kelimpahan individu, famili Braconidae dominan pada hutan sedangkan famili Scelionidae dominan pada perkebunan kelapa sawit dan area pasca tambang timah.
Kelimpahan relatif Braconidae pada hutan sebesar $26,14 \%$. Kelimpahan relatif Scelionidae pada perkebunan kelapa sawit dan area pasca tambang timah berturutturut adalah 24,45\% dan 35,78\%. Penelitian Yaherwandi et al. (2008) melaporkan bahwa kelimpahan Hymenoptera Parasitika berkorelasi positif dengan kelimpahan serangga fitofag.

Famili Braconidae pada hutan memiliki morfospesies dan kelimpahan individu yang lebih tinggi dibandingkan dengan dua tipe ekosistem lainnya. Famili Braconidae merupakan endoparasitoid primer pada larva Lepidoptera, Coleoptera dan Diptera dan tergolong ke dalam jenis parasitoid yang spesifik inang atau spesialis

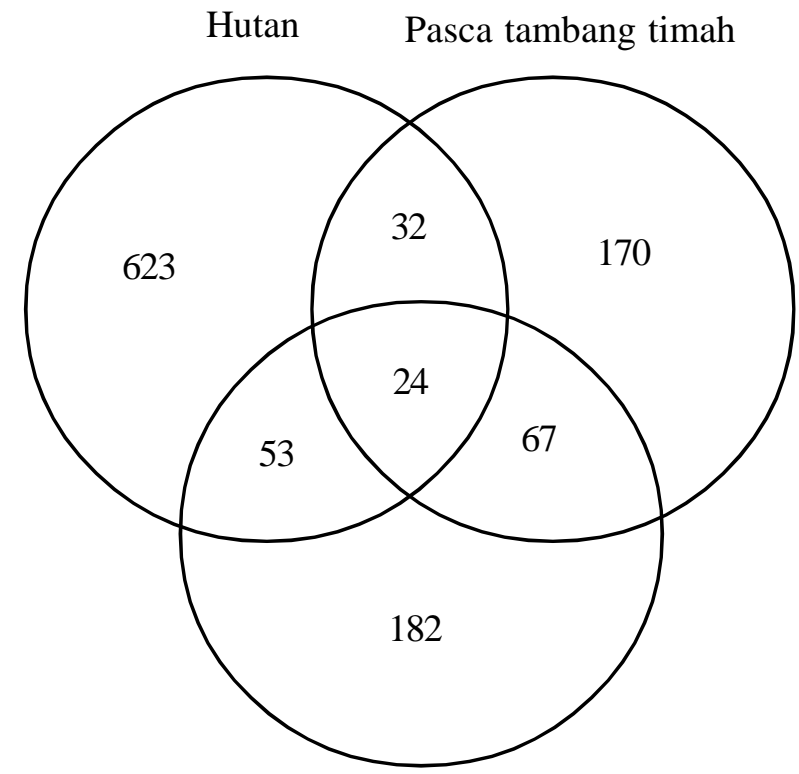

Perkebunan kelapa sawit

Gambar 2. Kesamaan morfospesies Hymenoptera parasitika dalam diagram Venn pada masing-masing ekosistem

Tabel 2. Jumlah spesies tumbuhan yang ditemukan pada masing-masing tipe ekosistem

\begin{tabular}{lccc}
\hline & \multicolumn{4}{c}{ Ekosistem } \\
\cline { 2 - 4 } Habitus & Hutan & $\begin{array}{c}\text { Perkebunan } \\
\text { kelapa sawit }\end{array}$ & Pasca tambang timah \\
\hline Rumput & 0 & 10 & 12 \\
Herba & 5 & 17 & 8 \\
Liana & 4 & 2 & 1 \\
Semak & 9 & 5 & 4 \\
Pohon & 46 & 1 & 5 \\
Total & 64 & 35 & 30 \\
\hline
\end{tabular}


(Wharton, 1997) sehingga kehadirannya pada suatu ekosistem berkaitan erat dengan serangga inangnya yang berada di ekosistem. Menurut Shaw (2006), parasitoid spesialis sangat tergantung pada ketersedian spesies serangga tertentu yang menjadi inangnya. Rendahnya kelimpahan Braconidae pada perkebunan kelapa sawit dan area pasca tambang timah berkaitan dengan kelimpahan inang. Penelitian Ruiz-Guerra et al. (2015) menyatakan bahwa kelimpahan Braconidae di suatu ekosistem berkorelasi positif terhadap kelimpahan inangnya.

Berbeda dengan ekosistem hutan, kelimpahan Scelionidae mendominasi pada ekosistem perkebunan kelapa sawit dan area pasca tambang timah. Kelimpahan Scelionidae berkaitan dengan kepadatan inangnya
(Noyes, 1989). Scelionidae merupakan jenis parasitoid generalis yang memarasit berbagai telur serangga dan laba-laba sehingga mempunyai potensial inang yang luas (Noyes, 1989; Masner, 1993). Kelimpahan Scelionidae lebih tinggi pada kondisi ekosistem yang terbuka dan terang (sunny habitats) seperti habitat padang rumput dibandingkan hutan (Masner, 1993). Perkebunan kelapa sawit dan area pasca tambang timah dalam penelitian ini merupakan daerah dengan area yang terbuka yang umumnya ditumbuhi tumbuhan vegetasi bawah seperti rerumputan dan herba.

\section{Pengaruh Tipe Ekosistem terhadap Keanekaragaman Hymenoptera Parasitika.} Komunitas Hymenoptera parasitika yang terdapat di

Tabel 3. Kelimpahan individu (N) dan kelimpahan relatif (\%) setiap famili Hymenoptera Parasitika pada masingmasing tipe ekosistem

\begin{tabular}{|c|c|c|c|c|c|c|c|}
\hline \multirow[t]{2}{*}{ Famili } & \multicolumn{2}{|c|}{ Hutan } & \multicolumn{2}{|c|}{$\begin{array}{l}\text { Perkebunan kelapa } \\
\text { sawit }\end{array}$} & \multicolumn{2}{|c|}{$\begin{array}{l}\text { Pasca tambang } \\
\text { timah }\end{array}$} & \multirow{2}{*}{$\begin{array}{c}\text { Total } \\
\text { Individu }\end{array}$} \\
\hline & $\mathrm{N}$ & $\%$ & $\mathrm{~N}$ & $\%$ & $\mathrm{~N}$ & $\%$ & \\
\hline Aphelinidae & 54 & 1,88 & 13 & 0,59 & 15 & 0,80 & 82 \\
\hline Bethylidae & 43 & 1,49 & 59 & 2,69 & 18 & 0,97 & 120 \\
\hline Braconidae & 752 & 26,14 & 318 & 14,48 & 156 & 8,37 & 1226 \\
\hline Ceraphronidae & 192 & 6,67 & 211 & 9,61 & 78 & 4,18 & 481 \\
\hline Chalcididae & 37 & 1,29 & 154 & 7,01 & 28 & 1,50 & 219 \\
\hline Chrysididae & 0 & 0,00 & 2 & 0,09 & 1 & 0,05 & 3 \\
\hline Diapriidae & 178 & 6,19 & 100 & 4,55 & 125 & 6,71 & 403 \\
\hline Dryinidae & 11 & 0,38 & 2 & 0,09 & 3 & 0,16 & 16 \\
\hline Elasmidae & 36 & 1,25 & 33 & 1,50 & 55 & 2,95 & 124 \\
\hline Encyrtidae & 320 & 11,12 & 159 & 7,24 & 99 & 5,31 & 578 \\
\hline Eucharitidae & 8 & 0,28 & 4 & 0,18 & 9 & 0,48 & 21 \\
\hline Eucoilidae & 63 & 2,19 & 34 & 1,55 & 11 & 0,59 & 108 \\
\hline Eulophidae & 328 & 11,40 & 244 & 11,11 & 178 & 9,55 & 750 \\
\hline Eupelmidae & 22 & 0,76 & 9 & 0,41 & 30 & 1,61 & 61 \\
\hline Eurytomidae & 12 & 0,42 & 7 & 0,32 & 24 & 1,29 & 43 \\
\hline Evaniidae & 12 & 0,42 & 33 & 1,50 & 89 & 4,77 & 134 \\
\hline Gasteruptiidae & 1 & 0,03 & 0 & 0,00 & 1 & 0,05 & 2 \\
\hline Ichneumonidae & 114 & 3,96 & 29 & 1,32 & 57 & 3,06 & 200 \\
\hline Megaspilidae & 0 & 0,00 & 0 & 0,00 & 1 & 0,05 & 1 \\
\hline Mutillidae & 7 & 0,24 & 1 & 0,05 & 3 & 0,16 & 11 \\
\hline Mymaridae & 88 & 3,06 & 66 & 3,01 & 96 & 5,15 & 250 \\
\hline Mymarommatidae & 0 & 0,00 & 0 & 0,00 & 2 & 0,11 & 2 \\
\hline Ormyridae & 1 & 0,03 & 0 & 0,00 & 0 & 0,00 & 1 \\
\hline Perilampidae & 0 & 0,00 & 6 & 0,27 & 1 & 0,05 & 7 \\
\hline Platygastridae & 237 & 8,24 & 83 & 3,78 & 38 & 2,04 & 358 \\
\hline Pteromalidae & 75 & 2,61 & 68 & 3,10 & 13 & 0,70 & 156 \\
\hline Scelionidae & 251 & 8,72 & 537 & 24,45 & 667 & 35,78 & 1455 \\
\hline Scoliidae & 2 & 0,07 & 4 & 0,18 & 8 & 0,43 & 14 \\
\hline Signiphoridae & 0 & 0,00 & 0 & 0,00 & 1 & 0,05 & 1 \\
\hline Tiphiidae & 1 & 0,03 & 0 & 0,00 & 5 & 0,27 & 6 \\
\hline Torymidae & 10 & 0,35 & 3 & 0,14 & 9 & 0,48 & 22 \\
\hline Trichogrammatidae & 22 & 0,76 & 17 & 0,70 & 43 & 2,31 & 82 \\
\hline Total & 2877 & 100 & 2196 & 100 & 1864 & 100 & 6937 \\
\hline
\end{tabular}


Tabel 4. Pengaruh tipe ekosistem terhadap kekayaan morfospesies (S), kelimpahan individu (N), indeks keanekaragaman Shannon-Wiener (H') dan indeks kemerataan spesies Hymenoptera Parasitika (E)

\begin{tabular}{lcccc}
\hline \multicolumn{1}{r}{ Tipe ekosistem } & $\mathrm{S}$ & $\mathrm{N}$ & $\mathrm{H}^{\prime}$ & $\mathrm{E}$ \\
\hline Hutan & $314,33 \mathrm{a}$ & 959,00 & $5,15 \mathrm{a}$ & $0,90 \mathrm{a}$ \\
Perkebunan kelapa sawit & $140,67 \mathrm{~b}$ & 732,00 & $4,09 \mathrm{~b}$ & $0,83 \mathrm{~b}$ \\
Pasca tambang timah & $138,00 \mathrm{~b}$ & 621,30 & $4,10 \mathrm{~b}$ & $0,83 \mathrm{~b}$ \\
\hline
\end{tabular}

Angka yang diikuti huruf yang sama pada satu kolom menunjukkan nilai yang tidak berbeda nyata berdasarkan uji DMRT dengan taraf nyata $5 \%$.

hutan, perkebunan kelapa sawit dan area pasca tambang timah tergolong ke dalam nilai yang tinggi $\left(\mathrm{H}^{\prime}>3\right)$ berdasarkan indeks keanekaragam Shannon-Wiener (Magurran, 1988) (Tabel 4). Komunitas Hymenoptera Parasitika dipengaruhi oleh tipe ekosistem $(p=0,001)$. Komunitas Hymenoptera parasitika pada hutan lebih tinggi dan berbeda sangat nyata dibandingkan dengan komunitas Hymenoptera parasitika pada perkebunan kelapa sawit dan area pasca tambang timah berdasarkan indeks keanekaragaman Shannon-Wiener. Hasil yang berbeda tidak nyata terdapat pada kelimpahan individu $(p=0,363)$.

Komunitas Hymenoptera parasitika pada hutan mempunyai keanekaragaman jenis lebih tinggi dibandingkan dengan komunitas-komunitas yang dipengaruhi oleh gangguan tertentu seperti pada agroekosistem atau lahan terganggu (Maeto et al., 2009; Ruiz-Guerra et al., 2015). Indeks keanekaragaman Shannon-wiener tergantung dari kekayaan spesies dan kemerataan spesies. Jumlah morfospesies dan indeks kemerataan Hymenoptera Parasitika lebih tinggi di hutan dibandingkan dengan dua lokasi lainnya sehingga komunitas Hymenoptera parasitika pada hutan mempunyai indeks Shannon-Wiener yang lebih tinggi.

Tipe ekosistem berpengaruh terhadap kekayaan morfospesies Hymenoptera Parasitika $(p=0,010)$. Tipe ekosistem berpengaruh terhadap kekayaan spesies Hymenoptera parasitika juga dilaporkan oleh Maeto et al. (2009) dan Ruiz-Guerra et al. (2015). Morfospesies Hymenoptera Parasitika di hutan lebih tinggi dan berbeda nyata dibandingkan dengan dua habitat lainnya (Tabel 4).

Kekayaan spesies Hymenoptera parasitika berkaitan dengan keanekaragaman tumbuhan yang terdapat di ekosistem (Maeto et al., 2009). Semakin beragam spesies tumbuhan maka makin beragam serangga herbivor yang merupakan inang yang umum diparasit oleh Hymenoptera parasitika. Selain itu, jenis tumbuhan dan arsitektur tumbuhan yang kompleks pada suatu ekosistem akan meningkatkan keanekaragaman parasitoid (Hawkins \& Lawton, 1987).

\section{SIMPULAN}

Keanekaragaman morfospesies Hymenoptera Parasitika lebih tinggi di hutan dibandingkan dengan perkebunan kelapa sawit dan area pasca tambang timah. Famili Braconidae ditemukan dominan di hutan akan tetapi pada perkebunan kelapa sawit dan area pasca tambang timah famili Scelionidae ditemukan lebih dominan.

\section{SANWACANA}

Penulis mengucapkan terima kasih kepada Direktorat Pendidik dan Tenaga Kependidikan, Direktorat Jendral Pendidikan Tinggi, Kemeterian Pendidikan dan Kebudayaan Republik Indonesia yang telah memberikan beasiswa pendidikan pascasarjana melalui Program Beasiswa Pendidikan Pascasarjana Dalam Negeri 2013 (BPP-DN 2013).

\section{DAFTAR PUSTAKA}

Adriadi A, Chairul, \& Solfiyeni. 2012. Analisis vegetasi gulma pada perkebunan kelapa sawit (Elaeis guineensis Jacq.) di Kilangan, Muaro Bulian, Batang Hari. J.Bio. UA. 1(2):108-115.

[BSN] Badan Standarisasi Nasional. 2011. Pengukuran dan Penghitungan Cadangan KarbonPengukuran Lapangan untuk Penaksiran Cadangan Karbon Hutan (Ground Based Forest Carbon Accounting). Badan Standarisasi Nasional, Jakarta.

Gibson GA, Huber JT, \& Woolley JB. 1997. Annotated Keys to the Genera of Nearctic Chalcidoidea (Hymenoptera). NRC Research Press, Ottawa.

Goulet H \& Huber JT. 1993. Hymenoptera of the World: An Identification Guide to Families. Canada Communications Group, Ottawa. 
Grimaldi D \& Engel MS. 2005. Evolution of the Insects. Cambridge University Press, New York.

Grissell EE \& Schauff ME. 1990. A Handbook of the Families of Nearctic Chalcidoidea (Hymenoptera). The Entomological Society of Washington, Washington.

Hamid H, Buchori D, \& Triwidodo H. 2003. Keanekaragaman parasitoid dan parasitisasinya pada pertanaman padi di kawasan Taman Nasional Gunung Halimun. Hayati. 10: 85-90.

Hawkins BA \& Lawton JH. 1987. Species richness for parasitoids of British phytophagous insects. Nature. 326: 788-790.

Lestari T, Abdi Z, Widodo J, \& Yohanes. 2008. Analisis vegetasi di lahan bekas penambangan timah Desa Rebo, Kabupaten Bangka. Enviagro. 2: 1-28.

Maeto K, Noerdjito WA, Belokobylskij SA, \& Fukuyama K. 2009. Recovery of species diversity and composition of braconid parasitic wasps after reforestation of degraded grasslands in lowland East Kalimantan. J. Insect. Conserv. 13(2): 245257.

Magurran AE. 1988. Ecological Diversity and Its Measurement. Princeton University Press, New Jersey.

Masner L. 1993. Superfamily Platygastroidea. In: Goulet H \& Huber JT (Eds.). Hymenoptera of the World: An Identification Guide to Families. pp. 558565. Canada Communications Group, Ottawa.

Noyes JS. 1989. A study of five methods of sampling Hymenoptera (Insecta) in tropical rainforest, with special reference to the parasitica. J. Nat. Hist. 23: 285-298.

Nurtjahya E. 2008. Revegetasi lahan pasca tambang timah dengan berbagai jenis pohon lokal di Pulau Bangka [Disertasi]. Institut Pertanian Bogor, Bogor.

Quicke DLJ. 1997. Parasitic Wasps. Chapman and Hall, London.

Rott AS \& Godfray HCJ. 2000. The structure of a leafminer-parasitoid community. J. Anim. Ecol. 69(2): 274-289.
Ruiz-Guerra B, López-Acosta JC, Zaldivar-Riverón A, \& Velázquez-Rosas N. 2015. Braconidae (Hymenoptera: Ichneumonoidea) abundance and richness in four types of land use and preserved rain forest in southern Mexico. Rev. Mexi. Biodivers. 86(1): 164-171.

Sahari B. 2012. Struktur komunitas parasitoid Hymenoptera di perkebunan kelapa sawit, Desa Pandu Senjaya, Kecamatan Pangkalan Lada Kalimantan Tengah [Disertasi]. Institut Pertanian Bogor, Bogor.

Sharkey MJ. 2007. Phylogeny and classification of Hymenoptera. Zootaxa. 1668: 521-548.

Shaw MR. 2006. Habitat considerations for parasitic wasps (Hymenoptera). J. Insect. Conserv. 10(2): 117-127.

Sperber CF, Nakayama K, Valverde MJ, \& Neves FDS. 2004. Tree species richness and density affect parasitoid diversity in cacao agroforestry. Basic. Appl. Ecol. 5(3):241-251.

Spurr SH \& Barnes BV. 1980. Forest Ecology. John Willey and Sons, New York.

Wharton RA. 1997. Manual of the new world genera of the family Braconidae (Hymenoptera): introduction. In: Wharton RA, Marsh PM, \& Sharkey MJ (Eds.). Manual of the New World Genera of the Family Braconidae (Hymenoptera). pp: 1-12. The International Society of Hymenopterist, Washington.

Yaherwandi, Manuwoto S, Buchori D, Hidayat P, \& Prasetyo LB. 2007. Keanekaragaman Hymenoptera parasitoid pada struktur lanskap pertanian berbeda di Daerah Aliran Sungai (DAS) Cianjur, Jawa Barat. J. HPT. Tropika. 7(1): 1020.

Yaherwandi, Manuwoto S, Buchori D, Hidayat P, \& Prasetyo LB. 2008. Struktur komunitas Hymenoptera parasitoid pada tumbuhan liar di sekitar pertanaman padi di Daerah Aliran Sungai (DAS) Cianjur, Jawa Barat. J. HPT. Tropika. 8(2): 90-101. 